\title{
Retorika Deliberatif Selebgram dalam Memotivasi Audiens Melalui Media Sosial (Konten "Level Up" di Akun Instagram Benakribo)
}

\author{
Jerry Alberico, Riris Loisa \\ jerry.915150171@stu.untar.ac.id,ririsl@fikom.untar.ac.id \\ Fakultas Ilmu Komunikasi Universitas Tarumanagara
}

\begin{abstract}
The media is growing very rapidly throughout the world, including in Indonesia. Along with the emergence of new media, there are also some new comers. One of them is Benazio Rizki Putra, who has started a career in social media since 2008 until now. Currently, Bena is known for his motivational content entitled "Level Up" on Instagram. This research examines how the deliberative rhetoric of Benazio motivates audiences through social media, based on the theory of rhetoric which includes rhetorical canons and supporting factors for rhetoric effectiveness. This study applied a qualitative case study method. This reseacrh found that Bena applied rhetorical canons and several factors supporting the effectiveness of rhetoric. This study concludes, the deliberative rhetoric applied by the selebgram is based on experience and delivered straightforwardly. The rhetorical canon which is characterized by the discovery of creative ideas using mind mapping, the style of language used is also relevant to nowadays trend and used familiar approach. Sometimes, the regulatory structure adopts the logic of forensic rhetoric. Besides that, it appears that the selebgram as communicators is convincing the audience so he can motivate his followers. Therefore, the attitude given by his followers also shows an open and positive attitude.
\end{abstract}

Keywords: Deliberative Rethoric, Motivation, Social Media

\begin{abstract}
Abstrak
Media berkembang dengan sangat cepat di seluruh dunia, termasuk di Indonesia. Seiring dengan munculnya media baru, terdapat pula beberapa orang yang menjadi selebgram baru. Salah satunya Benazio Rizki Putra, yang sudah mulai berkarir di media sosial sejak tahun 2008 hingga sekarang. Saat ini, Bena dikenal melalui konten motivasinya yang berjudul "Level Up" di media sosial Instagram. Penulis meneliti bagaimana retorika deliberatif dari Benazio dalam memotivasi audiens melalui media sosial. Berdasarkan teori retorika yang meliputi kanon retorika dan faktor pendukung efektivitas retorika, penelitian ini menggunakan metode studi kasus kualitatif. Penulis menemukan bahwa Bena menerapkan kanon retorika dan beberapa faktor pendukung efektivitas retorika. Penelitian ini menyimpulkan, retorika deliberatif yang diterapkan oleh selebgram ini didasari pengalaman dan bersifat terus terang. Kanon retorika bercirikan penemuan ide yang kreatif dengan menggunakan mind mapping, gaya bahasa yang digunakan juga bersifat kekinian dan terkesan akrab. Struktur pengaturan ada kalanya mengadopsi logika retorika forensik. Disamping itu, terlihat bahwa selebgram merupakan komunikator yang meyakinkan, sehingga dapat memotivasi followers-nya. Oleh karena itu, sikap yang diberikan oleh para followers juga menunjukkan sikap yang terbuka dan positif.
\end{abstract}

Kata kunci: Retorika Deliberatif, Motivasi, Media Sosial 


\section{Pendahuluan}

Media baru (new media) merupakan teknologi berbasis komputer yang tidak hanya berfungsi untuk memberikan informasi tetapi juga berfungsi untuk saling tukar informasi, seperti komputer, internet, terminal video teks, kabel digital dan sebagainya (West \& Turner, 2008). Dalam hal ini, Instagram yang berbasis internet juga menyalurkan video yang juga menyalurkan audio. Pada video "Level Up" yang dibuat oleh Benazio, tentunya memiliki suatu pesan tersendiri untuk para pendengarnya. Pesan merupakan sesuatu yang disampaikan oleh komunikator kepada komunikan melalui proses komunikasi (Tasmara, 1987). Keberhasilan komunikator juga terpengaruhi oleh bagaimana komunikator itu menyampaikan pesannya, apakah sang komunikator berhasil meyakinkan para pendengarnya dengan segala yang terlihat maupun terdengar. Maka dari itu, retorika dari penyampaian Benazio di video "Level Up" cukup menarik untuk diteliti.

Retorika menurut Dori Wuwur Hendrikus (2011: 14) adalah kesenian untuk berbicara baik, yang dicapai berdasarkan bakat alami (talenta) dan keterampilan teknis. Umumnya, retorika melihat bagaimana penyampaian pesan yang disampaikan oleh komunikator agar efektif sampai kepada para pendengarnya. Ada perspektif-perspektif yang digunakan dalam meneliti menggunakan retorika. Retorika, juga merupakan teknik pembujukan dengan menggunakan pembicaraan. Dalam penyampaiannya, retorika mempunyai unsur yang cukup mempengaruhi keberhasilan komunikator dalam menyampaikan pesan.

Penelitian ini ingin mengetahui bagaimana retorika deliberatif selebgram dalam memotivasi audiens melalui media sosial. Retorika yang dilakukan bukan hanya meliputi bahasa dari teks dalam pidatonya, tetapi juga meliputi gerak-gerik tubuh dan bahasa non-verbal untuk memperlihatkan retorika. Penelitian ini menganalisis retorika dari konten video motivasi oleh akun Instagram Benakribo yang berjudul "Level Up". Penelitian ini mengumpulkan data dengan melakukan wawancara terhadap narasumber dan juga mengobservasi komentar dari konten video tersebut.

Colquitt, LePinde, dan Wesson (2011: 179) memberikan definisi motivasi sebagai sekumpulan kekuatan energetik yang dimulai dari dalam maupun diluar individu, dimulai dari usaha yang berkaitan dengan pekerjaan, dan mempertimbangkan arah, intensitas dan ketekunannya. Media sosial, menurut Boyd (Nasrullah, 2017: 11) adalah kumpulan perangkat lunak yang memungkinkan individu ataupun komunitas untuk berkumpul, berbagi, berkomunikasi, dan dalam kasus tertentu saling berkolaborasi atau bermain. Media sosial memiliki kekuatan pada usergenerated content (UGC).konten yang dihasilkan oleh pengguna, bukan oleh editor sebagaimana di institusi media massa.

Retorika menurut Dori Wuwur Hendrikus (Wuwur, 2011: 14), berarti kesenian untuk berbicara baik, yang dicapai berdasarkan bakat alami (talenta) dan keterampilan teknis. Kesenian berbicara ini bukan hanya berarti berbicara lancar tanpa jalan pikiran yang jelas dan tanpa isi, melainkan suatu kemampuan untuk berbicara dan berpidato secara singkat, jelas, padat, dan mengesankan.

Retorika modern (Wuwur, 2011: 14) adalah gabungan yang serasi antara pengetahuan, pikiran, kesenian dan kesanggupan berbicara. Dalam bahasa percakapan atau bahasa populer, retorika berarti pada tempat yang tepat, pada waktu yang tepat, atas dcara yang lebih efektif, mengucapkan kata-kata yang tepat, benar dan mengesankan. Itu berarti orang harus dapat berbicara jelas, singkat dan efektif. 
Walaupun tulisan dalam retorika berfokus pada persuasi, kanon-kanon ini telah diterapkan di dalam beberapa situasi berbicara. Aristoteles menyatakan ada lima hal yang dibutuhkan untuk pidato yang efektif: penemuan, pengaturan, gaya, penyampaian, dan ingatan (West \& Turner, 2010: 11).

Tabel 1. Lima Kanon Retorika

\begin{tabular}{|c|c|c|}
\hline Kanon & Definisi & Deskripsi \\
\hline Penemuan & $\begin{array}{l}\text { Integrasi cara } \\
\text { berpikir dan argumen } \\
\text { di dalam pidato }\end{array}$ & $\begin{array}{l}\text { Menggunakan logika dan bukti di dalam } \\
\text { pidato membuat sebuah pidato menjadi } \\
\text { lebih kuat dan persuasif. }\end{array}$ \\
\hline Pengaturan & Organisasi dari pidato & $\begin{array}{l}\text { Mempertahankan struktur suatu pidato } \\
\text { (pengantar, batang tubuh, kesimpulan) } \\
\text { mendukung kredibilitas pembicara, } \\
\text { menambah tingkat persuasi dan } \\
\text { mengurangi rasa frustasi pada pendengar. }\end{array}$ \\
\hline Gaya & $\begin{array}{l}\text { Penggunaan bahasa } \\
\text { di dalam pidato }\end{array}$ & $\begin{array}{l}\text { Penggunaan gaya memastikan bahwa } \\
\text { suatu pidato dapat diingat dan bahwa ide- } \\
\text { ide dari pembicara diperjelas. }\end{array}$ \\
\hline Penyampaian & $\begin{array}{l}\text { Presentasi } \\
\text { pidato }\end{array}$ & $\begin{array}{l}\text { Penyampaian yang efektif mendukung } \\
\text { kata-kata pembicara dan membantu } \\
\text { mengurangi ketegangan pembicara. }\end{array}$ \\
\hline Ingatan & $\begin{array}{l}\text { Penyimpanan } \\
\text { informasi di dalam } \\
\text { benak pembicara }\end{array}$ & $\begin{array}{l}\text { Mengetahui apa yang akan dikatakan dan } \\
\text { kapan mengatakannya meredakan } \\
\text { ketegangan pembicara dan } \\
\text { memungkinkan pembicara untuk } \\
\text { merespons hal-hal yang tidak terduga. }\end{array}$ \\
\hline
\end{tabular}

(Sumber: West \& Turner, 2010: 11)

\section{Metode Penelitian}

Penelitian ini menggunakan metode pendekatan kualitatif dengan subyek penelitian terhadap Benazio Rizki Putra, dan obyek penelitian yakni konten video "Level Up" yang dibagikan di media sosial Instagram. Metode pengumpulan data yang digunakan adalah dengan wawancara secara mendalam, observasi, dokumentasi dan studi kepustakaan.

Teknik dalam menganalisis data penelitian ini adalah dengan menggunakan teknik analisis data model interaktif, seperti yang dipaparkan oleh Miles \& Huberman (Gunawan, 2014: 210 - 211). Terdapat tiga tahapan yang harus dikerjakan dalam menganalisis data penelitian kualitatif, yaitu reduksi data, paparan data, dan penarikan kesimpulan maupun verifikasi. Analisis data kualitatif dilakukan secara bersamaan dengan proses pengumpulan data berlangsung, artinya kegiatan-kegiatan tersebut dilakukan juga selama dan sesudah pengumpulan data. 


\section{Hasil Temuan dan Diskusi}

Retorika untuk memotivasi ke arah yang lebih baik. Tujuan awalnya memang dikatakan hanya karena kegeraman dengan kondisi problematika anak jaman sekarang yang malas dan semacamnya, namun memang dirasakan cukup penting untuk diposting. Bena menilai anak-anak muda jaman sekarang banyak yang malas dan mengeluh. Oleh karenanya, Bena berusaha untuk menyemangati anak muda dengan sharing. Dari situlah terpikirkan oleh Bena untuk membuat video dengan nama Level $U p$, karena mudah untuk disebut dan masih berhubungan dengan belajar.

\section{Retorika deliberatif yang terus terang}

Menurut Aristoteles, terdapat tiga jenis retorika yakni retorika forensik, retorika epideiktik, dan retorika deliberatif. Sesuai dengan tujuan yang dipaparkan oleh Bena bahwa motivasi yang dilakukan bertujuan untuk menyemangati anak muda dengan sharing, jelas terlihat bahwa yang dilakukan oleh Bena masuk ke dalam retorika deliberatif. Strategi yang digunakan agar tidak bertele-tele, karena permasalahan yang dibahas juga sudah sangat jelas. Agar audiens dari konten ini dapat tergerak dan tersadar dengan kata-kata yang disalurkan oleh Bena. Menurut Bena, anak muda jaman sekarang sebenarnya jika mau berpikir, pasti akan tahu solusi dari permasalahan mereka. Hanya saja terkadang mereka membutuhkan pendapat dari orang lain.

Instagram sebagai media sosial yang paling efektif dalam menyampaikan motivasi. Dalam menyalurkan motivasi, tentunya dibutuhkan wadah untuk penyalurannya. Salah satu wadah yang digunakan adalah media sosial. Dalam wawancara dengan Benazio, media sosial yang digunakan untuk menyalurkan konten motivasi tersebut cukup beragam, namun semua berawal dari Instagram dan YouTube. Setelah menggunakan kedua media tersebut, Bena juga sempat mencoba berbagi (share) di Twitter dan InstagramTV. Facebook juga pernah dicoba oleh Bena, namun terlihat kurang efektif karena pengguna Facebook di Indonesia sudah mulai berkurang. Bena tetap mencoba menggunakan semua platform. Efektivitas dari sebuah media menentukan keberhasilan dari penyaluran motivasi. Menurut Bena, media yang paling efektif adalah Instagram dan Podcast.

Penemuan ide dalam mencari topik dari selebgram yang kreatif. Permasalahan yang muncul dan digagas oleh Bena biasanya dari permasalahan umum anak sekolah, mahasiswa, maupun karyawan kantor. Biasanya Bena akan membuat mind map dari subjek tersebut dan mencari permasalahannya. Selain itu, Bena juga biasa mengandalkan QnA (Question and Answer) sebagai tempat munculnya topik-topik baru. Bena mengatakan bahwa segala yang dikatakannya sebagian besar adalah dari pengalaman yang sudah dialami. Bena meyakinkan melalui pengalamannya dari media sosial, selanjutnya di bidang content creation. Bena juga sudah pernah membangun perusahaan, jadi merasa mengerti mengenai start up, entrepreneur, dan sebagainya.

Pengaturan dari durasi video dan mencampurkan unsur retorika dalam beberapa videonya, mengorganisasikan kata-kata dari yang akan diucapkan juga dapat mempengaruhi efektivitas dalam memotivasi. Setiap motivator tentu mempunyai strategi tersendiri dalam memotivasi. Bena menjelaskan secara singkat bagaimana cara mengorganisasikan video Level $U p$ agar cukup efektif. Selain itu, terdapat pula beberapa video konten yang menggabungkan dari retorika deliberatif dengan retorika forensik. Sesuai dengan logika dari retorika forensik, adalah jenis retorika yang berkaitan dengan keadaan dimana pembicara mendorong timbulnya rasa bersalah atau 
tidak bersalah dari khalayak. Dalam beberapa video konten, Bena berusaha menimbulkan rasa bersalah ataupun menyadarkan audiens akan kesalahannya.

Gaya yang kekinian dari selebgram dan akrab menjadi suatu ciri khas dalam video konten. Gaya dari pembawaan dalam berpidato menjadi salah satu aspek penting, penggunaan bahasa dalam menyampaikan pidato. Bena bercerita lebih membawakan motivasinya dengan bahasa yang casual, karena target dari Bena merupakan anak-anak muda yang bahasa sehari-harinya tidak kaku, yang tidak terlalu serius.

Ingatan dari teks pidato yang spontan. Untuk mengetahui apa yang akan dibicarakan pada saat memberikan motivasi, setiap motivator tentu mempunyai caracara tersendiri dalam mengingatnya. Namun, Bena mengaku tidak mempunyai cara khusus tersendiri dalam mengingat kata-kata yang akan dibicarakan di dalam konten Level Up. Bena menjelaskan dalam menyampaikan motivasi, Bena lebih banyak membagikan cerita pengalaman daripada data. Bena juga menuturkan biasanya akan meng-edit videonya apabila pada saat menyampaikan kata-kata, mengalami "blank".

Ada beberapa faktor pendukung efektivitas retorika, ada dari komunikator, penerima, pesan dan medium. Pertama, dari komunikator. Dalam pengetahuan komunikasi dan keterampilan berkomunikasi, Bena mengaku sudah mempunyai pengalaman selama sepuluh tahun. Bena menjadi yakin dan percaya diri untuk membagikan pengalamannya, karena sudah terbiasa juga untuk berbicara di depan banyak orang, maupun mengisi acara-acara seminar dan talkshow.

Dalam suatu unggahan, terutama mengenai motivasi, akan menuai pro dan kontra. Hal itu tidak dapat dihindarkan dalam konten Level Up. Perbedaan pendapat pasti terjadi, namun Bena lebih memilih untuk membalas komentar yang ada dan menjadikan hal tersebut konten materi apabila yang dibahas cukup menarik. Dalam wawancara yang dilakukan, Bena mengaku tidak hanya mendapatkan inspirasi dari pengalaman pribadi, namun juga dapat berasal dari buku-buku yang dibaca, browsing di internet, maupun membaca berita serta artikel yang seru dan informatif.

Bena lebih memilih untuk berusaha membuat konten yang positif dan kreatif. Bena juga mengusahakan agar tidak ada konten-konten yang berbau negatif. Agar konten tersebut dapat dikonsumsi oleh siapa saja, dan dituturkan agar dapat dikatakan "family friendly". Bena mengaku tidak terlalu terpengaruh sisi budaya yang ada. Asalkan Bena dapat membuat konten yang positif dan kreatif, serta tanggung jawab sebagai content creator untuk menyajikan konten yang dapat dikonsumsi oleh target audiensnya.

Faktor pendukung efektivitas dari retorika salah satunya adalah pengetahuan komunikasi dan pengetahuan dari penerima. Bena menganggap bahwa sebenarnya target audiens dari konten Level $U p$ dapat memecahkan masalahnya sendiri jika ingin berpikir. Namun Bena juga menilai bahwa lebih banyak anak muda yang membutuhkan pendapat dari orang lain.

Target audiens dari konten Level Up merupakan anak sekolah dari jenjang Sekolah Menengah Pertama (SMP), Sekolah Menengah Atas (SMA), mahasiswa yang sedang kuliah, maupun fresh graduate atau first jobber. Jika dikategorikan dari usia, Bena menargetkan usia 15 hingga 25 tahun. Bena juga menjelaskan bahwa memilih target audiens seperti yang dipaparkan, karena memang sejak membuat video Level $U p$, pertama kali mempunyai kegemasan terhadap anak-anak muda.

Dari faktor-faktor pendukung pada penerima, penerima dinilai oleh narasumber sebagai penerima yang terbuka dan positif. Dari konten Level Up yang ada, Bena menilai respon dari target audiens sampai saat ini cukup bagus, banyak yang 
memberikan tanggapan maupun komentar. Menurut Bena, pendengarnya sesuai dengan materi yang disajikan. Oleh karena itu, Bena merasa respon yang diberikan oleh target audiens juga positif, hal tersebut membangkitkan semangat Bena untuk terus membuat konten Level Up.

Setiap audiens tentu mempunyai sisi kebudayaan dan sosial yang berbeda. Menurut Bena, audiens yang ada cukup beragam karena banyak yang meminta sharing mengenai topik-topik tertentu. Namun biasanya Bena menggunakan fitur Question and Answering $(Q n A)$ untuk mensortir pertanyaan-pertanyaan mengenai topik yang menarik. Setelah itu, Bena akan mengira-ngira jawaban yang tepat atas pertanyaan mengenai topik tersebut. Untuk mengatasi budaya yang berbeda, Bena tetap mengambil jalan tengah, yaitu lebih membahas menggunakan pendekatan gaya anak muda sesuai dengan target audiens. Contohnya menggunakan bahasa yang casual atau tidak kaku sehingga bisa tetap diterima oleh anak muda.

Dalam faktor pendukung pada pesan dan medium, ditemukan pesan yang digunakan oleh Bena adalah pesan yang konkrit. Dari segala yang disampaikan komunikator, itu harus memperhatikan elemen-elemen yang membentuk pesan. Elemen tersebut dapat berupa kata-kata, kalimat, intonasi suara, mimik wajah, maupun gerak gerik untuk memperjelas pesan yang ingin disampaikan. Pesan tidak selalu mengenai verbal. Namun ada juga non-verbal. Bena memaparkan bahwa intonasi suara yang digunakan lebih mengarah ke semangat dan menunjukkan percaya diri serta untuk tidak terlalu terbata-bata dalam menyampaikan pesan. Menurut Bena, di dalam video juga sangat penting untuk memperlihatkan wajah dari sang komunikator. Karena audiens pastinya mempunyai rasa ingin tahu akan wajah dari sang komunikator, agar dapat menilai.

Selain itu, Bena juga menjelaskan bahwa biasanya menggunakan pakaian yang spesifik, seperti contohnya pada saat sedang membahas materi yang santai, Bena akan memakai pakaian yang santai dan lebih mendekat ke anak muda. Sebaliknya apabila sedang membahas materi yang lebih serius, Bena lebih memilih untuk memakai pakaian seperti blazer agar terlihat wibawanya. Hal tersebut dilakukan agar dapat selalu memberi first impression kepada orang-orang yang baru pertama kali menonton konten Level $U p$ tersebut. Hal yang penting ketika membangun first impression, karena saat audiens menonton dan menurutnya bagus, maka audiens akan langsung percaya dengan orang yang dilihat.

Bena menjelaskan bahwa permainan waktu di dalam konten Level Up juga sangat penting. Audiens dari konten Level $U p$ rata-rata lebih nyaman mendengarkan materi yang tidak terlalu lama, hanya sekitar 5 hingga 15 menit. Biasanya, Bena akan merangkum dari materi yang ingin disampaikan agar hanya memakan waktu sekitar 5 menit. Namun, jika tidak ada batasan waktu, terangnya dapat berbicara lebih santai.

Proses pembeberan dari konten tersebut juga terbilang terbuka, karena Bena mempersilakan audiensnya untuk berkomentar dan menerima segala kritik maupun saran. Bena lebih banyak membalas komentar maupun memberikan "likes" atau semacamnya. Namun, jika di Podcast, biasanya di akhir Podcast, Bena akan berkata untuk share di Instagram story maupun membalasnya melalui Direct Message di Instagram. Biasanya dari respon yang diberikan oleh audiens itu, apabila ada yang menarik akan dicatat oleh Bena untuk dimasukkan ke dalam daftar materi yang akan dibahas berikutnya. 


\section{Kesimpulan}

Selebgram yang menyampaikan motivasi di dalam konten "Level Up" menggunakan beberapa media, seperti Instagram, Podcast, Facebook. Namun, dalam pandangan narasumber, dari semua media yang digunakan oleh narasumber, media Instagram adalah yang paling efektif.

Penggunaan retorika dari selebgram merupakan retorika deliberatif yang terus terang, dengan mengemukakan fakta-fakta berdasarkan kepada anak-anak muda jaman sekarang, menyampaikan pesan secara langsung ke sumber permasalahannya agar dapat dengan mudah dicari solusinya.

Penggunaan retorika dari selebgram digunakan agar memotivasi menuju arah yang lebih baik, dengan membahas permasalahan anak - anak muda jaman sekarang. Pemberian motivasi dari selebgram bersifat sukarela karena ingin berbagi pengalaman.

Cara penemuan topik yang didapatkan oleh selebgram terbilang kreatif dengan menggunakan mind mapping maupun QnA (Question and Answer). Penyampaian motivasi oleh selebgram adalah penyampaian yang kekinian dengan menggunakan bahasa yang informal dan lebih akrab kepada target audiensnya.

\section{Ucapan Terima Kasih}

Penulis mengucapkan ucapan terima kasih yang sebesar-besarnya kepada para narasumber dan seluruh pihak yang telah membantu penulis dalam melaksanakan penelitian ini sampai dengan selesai.

\section{Daftar Pustaka}

Hardyanti, Nicki. (2013). Analisis Retorika Dalam Kampanye Pemilukada DKI Jakarta 2012. Jurnal Komunikasi, 2(3). Mei 2, 2019. Terarsip di: https://jurnal.usu.ac.id/index.php/flow/article/view/9948

Hendrikus, Dori Wuwur. (2011). Retorika: Terampil Berpidato, Berdiskusi, Berargumentasi, Bernegosiasi. Yogyakarta: Kanisius.

Littlejohn, Stephen W \& Foss, Karen. (2009). Theories of Human Communication. Belmont, California: Thompson Learning.

Livia, L., \& Suenarto, S. (2015). Retorika Barack Hussein Obama Dan Susilo Bambang Yudhoyono Dalam Menanggapi Isu Isis Di Dunia. Jurnal Komunikasi, 7(1), 70-80. Mei 2, 2019. Terarsip di: https://journal.untar.ac.id/index.php/komunikasi/article/view/8

Maarif, Zainul. (2015). Retorika: Metode Komunikasi Publik. Jakarta: Rajawali Pers.

Nasrullah, Rulli. (2017). Media Sosial: Perspektif Komunikasi, Budaya, dan Sosioteknologi. Bandung: Simbiosa Rekatama Media.

Rakhmat, Jalaluddin. (2004). Retorika Modern: Pendekatan Praktis. Bandung: PT. Remaja Rosdakarya.

Saleh, G., \& Pitriani, R. (2018). Pengaruh Media Sosial Instagram dan WhatsApp Terhadap Pembentukan Budaya “Alone Together". Jurnal Komunikasi, 10(2), 103-114. Mei 2019. 2, Terarsip di: https://journal.untar.ac.id/index.php/komunikasi/article/view/2673/1708

Sutrisno, Isbandi \& Wiendijarti, Ida. (2014). Kajian Retorika Untuk Pengembangan Pengetahuan dan Ketrampilan Berpidato. Jurnal Komunikasi, 12(1), 71-84. Mei 2, 2019. Terarsip di: http://e-journal.uajy.ac.id/6444/2/KOM103771.pdf 
West, Richard. (2010). Introducing Communication Theory Fourth Edition. New York: McGraw-Hill.

Wibowo. (2017). Perilaku Dalam Organisasi. Depok: PT. RajaGrafindo Persada. Sumber Online:

https://tekno.kompas.com/read/2018/06/21/10280037/juni-2018-pengguna-aktifinstagram-tembus-1-miliar 